\section{Konference k 10. výročí Centra vizuální historie Malach: Prague Visual History and Digital Humanities Conference 2020,} 27.-28. 1.2020

V roce 2020 uplynulo deset let od založení Centra vizuální historie Malach při Ústavu formální a aplikované lingvistiky Matematicko-fyzikální fakulty Univerzity Karlovy. Během první dekády své existence se CVH Malach etablovalo jako průsečík humanitních a společenských věd s digitálními technologiemi. Stalo se uznávanou institucí, která se věnuje zejména orální historii a dějinám genocid. Základním kamenem činnosti CVH Malach je zpř́stupnění rozsáhlých sbírek orálněhistorických rozhovorů. CVH Malach původně vzniklo jako př́stupový bod k Archivu vizuální historie USC Shoah Foundation; tato stále rostoucí sbírka rozhovorů se svědky a přeživšími genocid, zejména holocaustu, v současnosti obsahuje téměř 55000 audiovizuálních nahrávek ve více než 40 jazycích. Od roku 2018 je v CVH Malach k dispozici též Fortunoffi̛v videoarchiv svědectví o holocaustu Yaleovy University s více než 4400 rozhovory. Návštěvníci mohou navíc pracovat i s menšími sbírkami: archivem Refugee Voices (150 anglických rozhovorů) a malou částí rozhovorů z Židovského centra holocaustu v Melbourne (15 rozhovorů s přeživšími narozenými na území Československa). Kromě přístupu do uvedených databází se $\mathrm{CVH}$ Malach podílí na výzkumných a vzdělávacích aktivitách, spolupracuje s dalšími fakultami Univerzity Karlovy a s domácími i zahraničními institucemi. V průběhu let se v Centru konaly vzdělávací semináře pro učitele $\mathrm{z}$ ČR i ze zahraničí, letní školy pro mezinárodní studenty a mnoho skupinových exkurzí vysokoškolských studentů různých oborů. V roce 2019 byl zahájen program stáží, který studentům umožňuje seznámit se $\mathrm{s}$ technologickými a obsahovými aspekty činnosti CVH Malach. U př́ležitosti 10. výročí existence CVH Malach byl tak i s ohledem na rozvíjející se náplň činnosti centra podstatně rozšířen i program pravidelné lednové konference, která byla nazvána Prague Visual History and Digital Humanities Conference (PraViDCo). První den konference (27. ledna) byl věnován zvaným přednáškám a diskusím zástupců partnerských institucí, zatímco ve druhém dni vystoupili domácí i zahraniční badatelé $\mathrm{v}$ klasickém konferenčním rámci na základě otevřené výzvy k zasílání příspěvků.

V dopolední části programu prvního dne vystoupili jako zvaní řečníci Martin Šmok z USC Shoah Foundation (s přednáškou „Education through genocide testimony: Visual History Archive of USC Shoah Foundation, IWitness and IWalks in the Czech schools") a následně Stephen Naron s Jakem Karou, zastupující Fortunoffův archiv (přednáška „Striking a Balance Between Ethics and Access: The Fortunoff Archive's Approach to the Digital Humanities“). Většina dalších hostujících řečníků následně vytvořila dva expertní panely. První $\mathrm{z}$ nich, nazvaný Institutions and Oral History in Europe, "Micro" and "Macro" Perspectives and Possibilities, Research and Technology, obsahoval príspěvky Adama Hradilka z Ústavu pro studium totalitních režimů, Natalie Otriščenko z Centra pro urbánní historii v Lvově, Michaela Loebensteina z Rakouského muzea filmu, a Martina Bulína ze Západočeské univerzity v Plzni. Diskuse směřovala od využití rozsáhlých archivů nahrávek orálněhistorických rozhovorů v badatelské a vzdělávací praxi, přes obecnější otázky spojené s interpretací audiovizuálního materiálu z hlediska filmové teorie, až k nejnovějším pokrokủm na poli počítačové lingvistiky a automatického zpracování mluvené řeči. Druhý expertní panel, nazvaný Interdisciplinary Research and Visual History Archival Collections, představil konkrétní výzkumné projekty Hany Kubátové zastupující Centrum pro transdisciplinární výzkum traumatu, násilí a spravedlnosti při Univerzitě Karlově a Ildikó Barna budapeštské Univerzity Loránda Eötvöse. Hana Kubátová pohovořila o tématu přináležitosti v kontextu osobní biografie; Ildikó Barna pak o využití komplementárních archivních zdrojů různého charakteru, zvláště tradičního archivního materiálu a orálněhistorických pramenů. První konferenční den uzavřelo předání cen vítězům komiksově-výtvarné soutěže a exkluzivní projekce dokumentárního filmu Terezinští hrobaři režisérky Olgy Struskové, který vznikl v produkci České televize. 
Druhý konferenční den (28. leden 2020) byl vyhrazen prríspěvkům zejména mladších badatelů z ČR i zahraničí, shromážděným na základě otevřené výzvy. První sekce této části konference se věnovala uplatnění digital humanities $\mathrm{v}$ historii. Začala príspěvkem „How to detect coup détat 800 years later" od Jana Škvrňáka, Jeremiho Ochaba a Michaela Škvrňáka z Masarykovy univerzity v Brně v České republice. Autoři uplatnili analýzu sociálních sítí na poměrně neobvyklém př́padu zkoumání politických spojenectví v českém království raného stř̌edověku s cílem rozplést mocenské vztahy a jejich vliv na tehdejší svět aristokracie. Mauricio Nicolas Vergara následně ve svém příspěvku popsal, jak podceňovaným prvkem byly prŕrodní katastrofy ve vojenských taženích první světové války v alpské oblasti - a podceňovaným faktorem zůstaly i při současném výkladu dějin. Jeho práce představuje prístup GIS (Geographic Information Systems), který umožňuje lepší pochopení tohoto jevu. Magdalena Sedlická a Wolfgang Schellenbacher z Masarykova ústavu Akademie věd ČR pak popsali proces tvorby databáze vizuální historie (EHRI Online Edition), založený na interdisciplinárním porozumění shromážděným materiálům, ale též zohlednění perspektivy koncového uživatele, vedoucí ke vzniku přínosného uživatelského rozhraní pro výzkumné pracovníky, učitele, studenty i širší veřejnost.

Druhá sekce byla zaměřena na různé přístupy k novým historickým pramenům v digitálním kontextu. Vanessa Hannesschläger z Rakouské akademie věd představila probíhající projekt, jehož cílem je reedice právních dokumentů rakouského spisovatele a novináře Karla Krause, vycházející z verze publikované knižně v 90. letech. Eva Grisová z Univerzity Jana Evangelisty Purkyně v Ústí nad Labem následně na konkrétním příkladu přibližila, jak mohou být audiovizuální nahrávky orálněhistorických svědectví využity i pro výzkum starších historických období. Ukázala, že i rozhovory věnované primárně holocaustu mohou být v kombinaci s dalšími prameny hodnotným zdrojem pro zkoumání dlouhého 19. století. Nataša Simeunović Bajić ze srbské Univerzity v Niši pak přibližila zajímavý fenomén známý jako Jugonostalgie, a to $v$ jeho internetové podobě. Prostřednictvím analýzy online archivů tištěných i filmových médií, YouTube videí, internetových médií a sociálních sítí autorka prozkoumala, jak se internetová sféra stává jakýmsi virtuálním muzeem a otevřeným prostorem pro sdílení a formování individuální i kolektivní paměti.

Třetí panel se podrobněji zaměřil na kvalitativní analýzu svědectví o holocaustu $\mathrm{v}$ audiovizuálních rozhovorech. Jakub Bronec z Univerzity $\mathrm{v}$ Lucemburku osvětlil málo známý prrípad československých Židů, kteří se rozhodli vyhledat úkryt v Lucembursku, ježovšem nebylo oním bezpečným útočištěm, po kterém toužili. Přiblížil systematické pronásledování těchto lidí, které je zkoumáno v rozsáhlejším výzkumném projektu, jenž využívá i orálněhistorické materiály. Následně se Karolína Bukovská z Freie Universität Berlin a Jakub Mlynář z Univerzity Karlovy ve společném příspěvku zaměřili na způsoby, jimiž je do rozhovoru vedeného metodou orální historie zapojeno zobrazení tetování přeživších koncentračního tábora $\mathrm{v}$ Osvětimi. Do popredí se zde dostal i často přehlížený vliv tazatelů a výzkumného kontextu na výslednou podobu rozhovoru.

Poslední sekce, nazvaná Identities, Beliefs and Humanism in the Modern Era, poskytla př́ležitost $\mathrm{k}$ širší konceptuální diskusi vybraných klíčových témat spojených s využitím audiovizuálních digitálních zdrojů ve vztahu $\mathrm{k}$ jejich tvůrcům a zprostředkovatelům. Deepika Kashyap z estonské Univerzity v Tartu se zabývala otázkou identity indické menšiny Nyishi, jak je reprezentována $\mathrm{v}$ on-line sfére prostřednictvím dokumentace kulturních prvků, které zachycují jejich identitu. Poté se Lauri Niemistö z finské Univerzity věnoval formám především vizuální reprezentace hnutí za práva žen v populárním britském satirickém časopise Punch mezi lety 1905 a 1914. Ukázal, že pro správné pochopení tropů a alegorií, které zprostředkovávají sociálně konstruované významy, je velmi důležité podrobně znát historický kontext. V dalším prríspěvku se Komlan Agbedahin $\mathrm{z}$ univerzity Svobodného státu $\mathrm{v}$ Jihoafrické republice zaměřil na nedávný skandál $\mathrm{z}$ afrického fotbalového šampionátu coby př́klad potlačení lidské důstojnosti a hodnoty lidského života ve snaze podrobit se obchodním a politickým 
zájmům. Poukázal též na skutečnost, že internetové zdroje umožňují rekonstrukci události včetně osobních svědectví fotbalistů, jejichž spoluhráči byli při vojenském incidentu zabiti. Celou konferenci pak uzavřel př́spěvek Karin Hofmeisterové z Univerzity Karlovy, která se věnovala reprezentacím mučednictví ve vizuální a textové produkci srbské pravoslavné církve a otázce kontinuity tohoto fenoménu s obdobím jugoslávského socialismu.

Dvoudenní konference poskytla vhled do široké palety různých témat, metod a prístupů, s nimiž přišlo $\mathrm{CVH}$ Malach do styku během prvních deseti let své existence. Příspěvky z druhého dne jsou shromážděny $\mathrm{v}$ konferenčním sborníku, který je již k dispozici i v elektronické podobě (https://ufal.mff.cuni.cz/malach/en /publications). Centrum bude bezesporu i nadále sloužit jako místo setkávání vědců, učitelů, studentů a všech, kteří mají zájem dozvědět se o zkušenosti lidí, kteří byli ochotni sdílet své životní příběhy navzdory prožitým tragédiím a utrpení.

Jiři Kocián - Jakub Mlynár DOI: 10.14712/23363525.2020.15 